\title{
Who knows best? Paternalism in Aboriginal policy
}

\author{
Emily Jeffes
}

University of Technology Sydney, Faculty of Arts and Social Sciences, PO Box 123, Ultimo

NSW 2007, Australia. emily.jeffes@student.uts.edu.au

\begin{abstract}
Through colonial eyes, Aboriginal and Torres Strait Islander people are seen as subjects void of agency. They have been treated by the Australian polity as though they are in great need of saving. This paper explores the ways in which wellintended policies and initiatives implemented by successive governments have failed to recognise and support Indigenous Australians as functioning sovereign beings.
\end{abstract}

Keywords: paternalism; Aboriginality; sovereignty; inequality

The treatment of Indigenous Australians has historically reflected a paternalist notion that the 'state knows best'. Policies and initiatives introduced by successive Australian governments pertaining to Indigenous Affairs have consistently reinforced the colonial construction of Aboriginal and Torres Strait Islander people as incapable of a functioning existence free from external support, protection and intervention. The 1967 Referendum resulted in constitutional changes that allowed the federal government to introduce laws specific to the Aboriginal 'race', ultimately expanding their authority in the everyday lives of Indigenous Australians. Top-down policies of guardianship that limit the agency of the individual continue to be implemented in Aboriginal Affairs, justified by the projected positive outcomes. Seeking to address disadvantage and inequality, policies such as the 2007 Northern Territory Intervention, ever-expanding management of welfare payments and initiatives to 'Close the Gap' are introduced with honourable intentions. However, they ultimately fail to recognise and support Indigenous Australians as functioning sovereign beings.

Aboriginal policy in Australia has consistently framed Indigenous Australians as subjects in need of support, protection, or salvation. The historical and ongoing implementation of paternalistic policies reflects a 'patronising and corrosive notion that governments know better' (Dennis 2013, p. 50). Paternalism is broadly understood as 'the interference with a person's liberty of action justified by reasons referring exclusively to the welfare, good, 
happiness, needs, interests or values of the persons being coerced' (Dworkin 1972, p. 65). The concept has a long history of criticism given the restriction it places on individual agency. 19th century British thinker John Stuart Mill, praised for his contributions to moral and political philosophy, posited that an individual's ability to make his own decisions should never be overruled (Dennis 2013). Equally influential German philosopher Immanuel Kant labelled paternalism as a threat to human dignity and free will, positioning the coerced or governed group as 'immature children unable to distinguish between what is truly useful or harmful to them' (Dennis 2013, p. 50). Inherently, paternalistic policies position the state as guardian, granting powers to infringe on individual agency where they observe a distinct or urgent need. Under this guise of guardianship, the Australian government has continually introduced Aboriginal policies that disregard Indigenous sovereignty and freedom.

The landslide victory of the 1967 referendum granted the Whitlam government and its successors power to pass legislation for Indigenous Australians, who had previously been excluded from federal law under Section 51. The constitutional changes meant Aboriginal Australians would be granted inclusion in the national census count. The wellbeing of the Aboriginal population was understood as contingent upon their inclusion in the nation (Rowse 2000). With all states voting in favour of the constitutional changes, the $90.77 \%$ 'Yes' vote represents the 'strongest endorsement of a referendum vote in Australian political history' (Attwood \& Markus 1997, p. 58). Its success reflected a symbolic shift in social consciousness towards inclusion of Aboriginal Australians in a non-discriminatory regime. In reality, the symbolic significance awarded to the referendum far outshines the material implications for Indigenous Australians. While the government gained the 'moral authority to expand the Commonwealth's role in Aboriginal Affairs' (Rowse 2000, p. 20), Indigenous communities remained relatively powerless under a paternalistic guardianship.

On the 17th of May 1967, the referendum established that the wellbeing and affairs of Aboriginal Australians were ultimately the responsibility of the Commonwealth (Attwood \& Markus 1997). Targeted ameliorative legislations to be imposed upon Indigenous communities were deemed necessary and beneficial. The national directorate of the 'Vote Yes' campaign had argued that, 'any Commonwealth laws in relation to Aborigines would be favourable to Aborigine's. In view of the special disadvantage of lack of capital, education and 'know-how' suffered by the Aborigines, the well-known principle of justice that is 'it is as unjust to treat unequals equally as to treat equals unequally' is a strong argument for special legislation to enable Aborigines to overcome their disadvantage' (Rowse 2000, p. 21). Arguably, empowering the government to make decisions for the benefit of Aboriginal Australians inevitably disempowered Indigenous communities from enacting their sovereignty. The constitutional changes that resulted from the 1967 referendum continue to allow the federal government to intervene in the lives of Aboriginal people without their consent.

Policy approaches have often rested upon the construction of representations of Aboriginality that support or justify the management, intervention or control of Aboriginal affairs. Following Foucault, it can be argued that 'discourses and discursive practices are important 
sites of power relations, constituting objects, events, identities, subjects and truths in particular ways, with material and other consequences' (Macoun 2011, p. 520). In this sense, representations not only reflect dominant realities and meanings but simultaneously produce them (Macoun 2011). Constructions of Aboriginality and the nature, culture and future of Aboriginal people have been used to justify policies of management and control (Macoun 2011).

The 2007 Northern Territory Intervention, announced under a conservative Howard government, typifies the application of these representations to Aboriginal crisis intervention. In 2007 then Prime Minister John Howard announced a military-led strategy of intervention into Aboriginal communities in the Northern Territory. The crisis intervention responded to the findings of the Little Children are Sacred report, which reported rampant levels of community violence against Aboriginal women and children (Watson 2009). With no negotiation or consultation with Indigenous communities, the federal government suspended the Racial Discrimination Act (1975) and enacted the Northern Territory National Emergency Response Bill (2007) (Watson 2009). The intervention included the quarantine and control of welfare payments, bans on alcohol and pornography, compulsory health checks for children, and the Commonwealth's acquisition of township leases over Aboriginal-owned land (Perche 2017). Media and public attention fell solely upon claims of child sexual abuse and its prevention and protection (Watson 2009). Widespread public concern supported a paternalistic intervention that undermined Indigenous sovereignty and proliferated the depiction of Aboriginal communities as requiring external support.

Architects and supporters of the Northern Territory Intervention used representations of Aboriginality as inherently violent and abusive to justify the program (Macoun 2011). Framing Aboriginal children as inherently vulnerable and subject to ongoing abuse and victimisation, Aboriginal adults were cast as inadequate protectors and carers, fellow victims, or complicit in the abuse (Macoun 2011). Addressing the House of Representatives in 2007, Howard emphasised a heightened sense of urgency proclaiming, 'there is no greater obligation... than the obligation for caring for the young and vulnerable' (Howard cited in Macoun 2011, p. 521). The dangerous conflation of Aboriginality with abuse depicted vulnerable children as in need of saving from Aboriginality itself, a notion reminiscent of the objectives of child protection and removal policies associated with the Stolen Generation. Thus, the intervention placed restrictions on the agency of Aboriginal families for the argued sake of their own children's benefit. Even as the programs' aims and objectives developed and changed, Aboriginal children remained the imagined beneficiaries. The representation of Aboriginality as inherently violent and abusive is particularly problematic given the Little Children are Sacred report 'indicated that a significant proportion of perpetrators of abuse of Aboriginal children were white' (Anderson and Wild 2007 cited in Macoun 2011). The implementation of a policy that valued new paternalism and guardianship over the support of Indigenous self-determination resulted in lasting psychological damage within Aboriginal communities stemming from welfare quarantining, stigmatisation through links to dysfunction and child abuse, and a loss of autonomy (Perche 2017). 
The income management welfare reform introduced under the Northern Territory National Emergency Response Bill (2007) and its subsequent expansion under successive governments is another paternalistic policy that has worked to position Aboriginal Australians as in need of support. Income management under the NT Intervention worked by 'quarantining' a percentage of individual welfare payments, including Newstart Allowance, Youth Allowance, Parenting Payment, Sickness Benefit and Special Benefit, to an account linked to an electronic debit card called the 'Basics Card' (Dee 2013, p. 273). This percentage of welfare was to be used only for 'essentials' such as food, rent and clothing and prohibited the purchase of alcohol, tobacco, pornography and gambling products and services (Dee 2013). The Basics Card was only accepted by select stores in the Northern Territory. The day-to-day lives of Indigenous Australians were highly controlled, reinforcing an underlying suggestion that they were not capable of managing their lives and money on their own. Restrictions placed on financial autonomy and the inherent lack of trust, particularly of Indigenous communities, is 'central to the operation of a paternalist welfare state' (Dee 2013, p. 274). This level of control echoes a long history of colonial management and surveillance. It also infers that Aboriginal communities are 'exclusively responsible for problems within their communities' (Yu, Duncan \& Grey 2008 cited in Dee 2013, p. 280), neglecting to acknowledge the structural disadvantages faced by Indigenous Australians that date back to colonial invasion.

In 2017, ten years after the Northern Territory Intervention, Prime Minister Malcolm Turnbull announced the introduction of the 'Indue Card', marking further expansion of welfare management in disadvantaged, and mostly Indigenous, communities. Initially trialled in Western Australian towns including Kununurra and Wyndham, welfare recipients were to have $80 \%$ of Centrelink payments relegated to an account linked to their Indue Card with the remaining 20\% withdrawable in cash (Davey 2017). The cashless welfare card was expanded into Queensland in late 2017 with around 6,700 individuals set to receive the compulsory card for a 12-month arrangement beginning in the 'dole capital of Australia', Bundaberg (Horn 2017). Much like its antecedent, the Basics Card, the loss of autonomy attached to the roll-out of the Indue Card had detrimental effects on the mental wellbeing of Indigenous communities. Chief executive of the national peak body for Aboriginal health NACCHO, Pat Turner, stated the cashless welfare card 'reminds Aboriginal people every day that they are treated as second- and third-class citizens in their own land' (Davey 2017). Welfare policies that position Aboriginal Australians as incapable of self-sufficiency and self-determination are dangerous given their contribution to the stigma surrounding Indigenous communities as dysfunctional and separate from mainstream Australian society.

It is important to emphasise that each of the discussed policies has been introduced with good intentions. Policies and reforms seeking to address widespread Indigenous disadvantage are indisputably essential. It is in the execution, not the aim, that paternalistic policies garner criticism. Characteristically, paternalism aims to improve the situation of those governed. Most of those involved in the removal and institutionalisation of Indigenous children during the Stolen Generation believed they were doing the right thing. Returning to this point here is essential in framing the following examination of the 'Closing the Gap' initiative. While the

NEW: 2019 
overall aims of the initiative are important, it can still be viewed as a manifestation of ongoing paternalism.

In March 2008, under the newly-elected Rudd Government, representatives from the federal government, the Aboriginal and Torres Strait Islander Social Justice Commission and peak Indigenous health bodies signed a Statement of Intent to "work together to achieve equality in health status and life expectancy between Aboriginal and Torres Strait Islander peoples and non-Indigenous Australians by the year 2030' (Human Rights and Equal Opportunity Commission 2008 cited in Pholi 2009, p. 1). The six targets laid out by the National Indigenous Health Equality council sought to address inequalities in life expectancy, child mortality rates, access to early childhood education, levels of literacy and numeracy among children, year 12 attainment rates and employment outcomes (Gardiner-Garden 2012). To achieve these goals, seven areas for investment were identified - early childhood, schooling, health, economic participation, healthy home, safe communities and governance and leadership (Pholi 2009). The federal government would report annually on the progress of the identified targets. Despite accounting for $\$ 3.5$ billion of the Commonwealth's annual expenditure (Gardiner-Garden 2012), Indigenous-specific programs have generated deeply disappointing results. Most poignantly, the 2018 annual report revealed that on average Indigenous Australians still die ten years younger than their non-Indigenous counterparts, admitting not even one year of improvement in the ten years since 2008 (Coleman 2018).

In order to achieve the deliverables promised by the Close the Gap initiative, the government has taken on the role of guardian, implementing top-down policies that aim to improve the wellbeing of Indigenous Australians. The goal of achieving 'statistical equality' is problematized by its 'predominantly individualistic focus, which fails to account for an imbalanced distribution of power and limited degree of control exercised by Aboriginal and Torres Strait Islander Australians (both individually and collectively) over their own circumstances' (Pholi 2009, p. 10). The reduction of the Indigenous population to a numeric issue has a hugely demoralising effect, framing the Aboriginal community as in need of measurement, monitoring and rectification (Pholi 2009). A reliance on statistical indicators, such as the biomedical and socio-economic aims of Close the Gap, fails to address the persisting inequality of power distribution in Australia. When compared to the Northern Territory Intervention and policies of welfare management, the Close the Gap initiative did attempt to work in partnership with, rather than imposing upon, Indigenous communities. However, in order to achieve real and lasting progress towards equality, further collaboration is needed to 'deliver control over the Indigenous affairs agenda into the hands of Indigenous Australians' (Pholi 2009, p. 10) and empower Indigenous Australians to exercise their rights and freedoms as sovereign beings.

Paternalism exercised by the Australian government over Indigenous communities is made possible by persisting imbalances of power. By framing Aboriginal and Torres Strait Islander people as subjects in need of support, protection, intervention, or salvation, policies that restrict and control individual liberties are justified by those imposing them as necessary and beneficial. Though stemming from good intentions, Indigenous-specific initiatives including 
the Northern Territory Intervention, welfare management, and Close the Gap typify Australian efforts to work for Indigenous communities not with them. Looking forward, it is imperative that non-Indigenous Australians focus on empowering and supporting Aboriginal and Torres Strait Islander people as functioning sovereign beings in order to address ongoing disparities and injustices that have persisted since colonial invasion.

\section{References}

Attwood, B. \& Markus, A. 1997, The 1967 Referendum, or when Aborigines didn't get the vote, Canberra: Aboriginal Studies Press, pp. 49-63.

Coleman, C 2018, 'The failures of Closing the Gap', The Saturday Paper, 17 February, viewed 13 June 2019, <https://www.thesaturdaypaper.com.au/opinion/topic/2018/02/17/thefailures-closing-the-gap/15187860005824>.

Davey, M. 2017, 'Cashless welfare card treats Aboriginal people as 'third-class citizens', The Guardian, 10 January, viewed 12 June 2019, <https://www.theguardian.com/australianews/2017/jan/10/cashless-welfare-card-treats-aboriginal-people-third-class-citizens $>$.

Dee, M. 2013, 'Welfare Surveillance, Income Management and New Paternalism in Australia', Surveillance and Society, vol. 11, no. 3, pp. 272-286.

Dennis, C. 2013, 'The ethics of paternalism in Aboriginal policy', Eureka Street, vol. 23, no. 19, pp. 49-52.

Dworkin, G. 1972, 'Paternalism', The Monist, vol. 56, no. 1, pp. 64-84.

Gardiner-Garden, J. 2012, 'Closing the Gap', Parliament of Australia, 28 September, viewed 13 June 2019,

$<$ https://www.aph.gov.au/About_Parliament/Parliamentary_Departments/Parliamentary_Libr ary/pubs/BriefingBook44p/ClosingGap>.

Horn, A. 'Welfare quarantine on the cards for thousands of Queenslanders in Wide Bay region', $A B C$ News, 21 September, viewed 12 June 2019,

<https://www.abc.net.au/news/2017-09-21/welfare-quarantine-on-the-cards-for-thousands-ofqueenslanders/8965774>.

Macoun, A. 2011, 'Aboriginality and the Northern Territory Intervention', Australian Journal of Political Science, vol. 46, no. 3, pp. 519-534.

Perche, D. 'Ten years on, it's time we learned the lessons from the failed Northern Territory Intervention', The Conversation, 26 June, viewed 11 June 2019, $<$ https://theconversation. com/ten-years-on-its-time-we-learned-the-lessons-from-the-failednorthern-territory-intervention-79198> .

NEW: 2019 
Pholi, K. 2009, 'Is 'Close the Gap' a useful approach to improving the health and wellbeing of Indigenous Australians?', Australian Review of Public Affairs, vol. 9, no. 2, pp. 1-13.

Rowse, T. 2000, 'The modest mandate of 1967', Obliged to be difficult: Nugget Coombs' Legacy in Indigenous Affairs, Cambridge, Cambridge University Press, pp. 17-33.

Watson, I. 2009, 'In the Northern Territory Intervention: what is saved or rescued and at what cost?', Cultural Studies Review, vol. 15, no. 2, pp. 45-60. 